\title{
The effect of composition and substrate fermentation duration on microbial fuel cell electrical energy
}

\author{
Christin Vera Natalia Ginting ${ }^{1,}{ }^{*}$, Jumaida Sari Nasution" ${ }^{1}$, Malik Alfatah Sembiring ${ }^{2}$ \\ and Murniaty Simorangkir ${ }^{1}$
}

'Department of Chemistry, Universitas Negeri Medan, Medan 20221, Indonesia

${ }^{2}$ Department of Physics, Universitas Negeri Medan, Medan 20221, Indonesia

${ }^{*}$ Corresponding author: (CVNG), christinginting21desember@gmail.com

DOI: 10.24114/jpkim.v1li3.15773

Received: 11 July 2019; Accepted: 29 October 2019

Abstract:

Organic vegetable wastes such as mustard vegetables found in traditional markets, especially Medan, are quite abundant and the increase in electricity demand is not matched by the availability of adequate energy sources, encouraging efforts to find alternative sources of renewable energy, economical and environmentally friendly. Microbial Fuel Cell (MFC) reactors can be used as an alternative energy source that converts chemical energy into electrical energy through biocatalytic reactions using microorganisms by utilizing organic materials. This study aims to determine the effect of the use of mustard vegetable waste substrate with a variety of starters and fermentation duration in the MFC reactor system to the voltage and current of electrical energy generated. The design of this study used a factorial 4x2 Completely Randomized Design consisting of two factors, namely factor A substrate composition and fermentation duration B factor. The results showed that there was an influence of substrate composition and fermentation duration on the MFC reactor system on the electrical energy generated by the system. Electricity (1) $(20.1 \mathrm{~mA})$ and voltage $(72.13 \mathrm{mV})$ highest electricity produced by MFC reactor with composition of glucose substrate and EM4 starter with 5 days fermentation duration, followed by the treatment of vegetable mustard waste and EM4 with a fermentation duration of 5 days $(15.2 \mathrm{~mA}$ and 68.76 $\mathrm{mV}$ ). In terms of economics, the use of vegetable mustard waste substrate material with EM4 starter in the MFC reactor has more potential to be developed than using glucose substrates which are relatively more expensive.

Keywords: Electric energy; fermentation duration; microbial fuel cell; mustard vegetable waste

\section{Introduction}

The abundance of organic waste such as vegetable waste such as mustard vegetables found in traditional markets, especially Medan. Can pollute the environment if it is disposed of carelessly.

In addition to the problem of waste, energy problems are also one of the problems that are often faced in the city of Medan. Increasing energy demand continues to increase but is not balanced with the availability of adequate energy sources. Therefore, a sustainable alternative energy source is needed to avoid an energy crisis. The Microbial Fuel Cell (MFC) reactor can be used as an alternative energy source that is environmentally friendly and can be a source of energy in the future (Chang et al. 2016a; Padey et al. 2011). MFC can convert chemical energy into electrical energy through biocatalytic reactions, which use microorganisms. MFC facilitates an oxidation reduction environment that can be controlled by the flow of electrons and makes it an ideal tool for processing organic matter into inorganic matter in microbial waste. Transfer 
mechanism electrons in the MFC anode are the main issue in understanding the theory of how MFC works (Liu and Logan, 2004). Microbies move electrons through an electron transport system consisting of a series of components of the bacterial extracellular matrix or together with the transfer of electrons dissolved in a mass solution (Chang et al. 2006b; Padey et al. 2011).

The use of microorganisms in biofuel cells can eliminate the isolation of individual enzymes so as to provide a cheaper substrate for fuel cells. Electricity has been produced using energy sources for complex needs of wastewater (Scott et al. 2007). Bacteria in MFC can be used to produce electricity while consuming waste (Romadhoni and Putu, 2014). Manufacture of alternative energy (biogas) can also use mustard vegetable waste mixed with livestock manure (Sari et al. 2015). Vegetable mustard is one type of vegetable that is widely marketed in the city of Medan and is the most common vegetable waste found in traditional market markets in the city of Medan. This vegetable mustard waste contains organic substances which can be described by fermentation by microbes. This study aims to determine the effect of the composition of the vegetable mustard waste substrate with starter manure, fermentation time, and its interaction using the MFC reactor system to the voltage and current of electrical energy produced system. The results of this study are expected to provide information to the people of Medan regarding the use of vegetable waste as raw material to produce electricity by using a reactor system Microbial Fuel Cell (MFC) as one of the alternative sources of renewable energy and environmentally friendly.

\section{Materials and Methods}

\section{Materials and chemicals}

The tools used in this study are MFC reactors (acrylic chumber, Nafion 121 membrane, graphite electrode), Masda 830B AVOMETER digital multitester, Basic meter (HERMA), cable, alligator clamp, lamp and nest, glas beaker and glass stirrer.

The materials used in this study are vegetable mustard waste from the traditional market MMTC and Medan Sambu, Cow Dung, Electrodes (graphite), Nafion 121 membrane, Aquades, $\mathrm{NaOH} 1 \mathrm{M}, \mathrm{HCl} 1 \mathrm{M}, \mathrm{KMnO}_{4} \mathrm{IM}$, phosphate buffer 0,1 $\mathrm{M}$, cling wrap, Aluminum foil, Glucose $1 \mathrm{M}$, EM4 bacteria, $\mathrm{H}_{2} \mathrm{O}_{2} 3 \%, \mathrm{H}_{2} \mathrm{SO}_{4} \mathrm{MM}$.

\section{Membrane preparation}

The membrane used in this study was 121 breaths which were first boiled with distilled water for 1 hour, then boiled with $\mathrm{H}_{2} \mathrm{O}_{2} 3 \%$ for 1 hour and washed with distilled water. The membrane was then boiled back with $\mathrm{H}_{2} \mathrm{SO}_{4} \mathrm{IM}$ for 1 hour then washed with distilled water 3 times. The membrane is stored (soaked) in distilled water until it will be used (Scott et al. 2007).

\section{Electrode preparation}

Graphite electrodes were soaked in $\mathrm{HCl} \mathrm{IM}$ solution for 1 day then rinsed with distilled water, after that the electrodes were soaked again into $\mathrm{NaOH} 1 \mathrm{M}$ solution for 1 day then rinsed again using distilled water. The electoda is soaked in distilled water solution until it will be used (Purwonoet et al. 2015).

\section{Substrate and stater preparation}

The substrate of vegetable mustard trash is cut into pieces and weighed as much as $200 \mathrm{gr}$. As much as 100 grams of mustard pieces are mixed with starter of cow dung and 100 grams of mustard pieces mixed with EM4 starter, then added with water and stirred, then let stand.

Substrate of glucose $1 \mathrm{M}$ solution was made by dissolving $40.54 \mathrm{~g}$ of glucose in $226 \mathrm{~mL}$ of distilled water. A total of $113 \mathrm{~mL}$ of glucosal solution was mixed with cow manure stater and 113 $\mathrm{mL}$ of glucose solution mixed with the EM4 bacteria stater, then water and stirred in each mixture then let stand. 


\section{Electrolyte preparation}

The electrolyte used is a potassium permanganate $\left(\mathrm{KMnO}_{4}\right) \mathrm{IM}$ solution by dissolving 71.8 grams of $\mathrm{KMnO}_{4}$ in distilled water to a solution volume of $450 \mathrm{~mL}$.

\section{Experiments of variations in substrate composition, status and duration of micro-fuelcell fractionation}

Provided 4 sets of MFC reactors. In the anode compatment each reactor is filled with a mixture of mustard substrate and stater cattle dung, a mixture of mustard and EM4 bacteria, a mixture of glucose and cow dung, a mixture of glucose and EM4 bacteria. phosphate buffer solution added. Each experiment variations on substrate composition and stater were repeated 3 times. In each experiment a measurement of the electrical energy produced by the MFC reactor (electric current ( $\mathrm{I}$ ) and voltage $(\mathrm{V})$ at the time after 5 days of fermentation and after 10 days of fermentation with the Masda 830B AVOMETER Digital Multitester.

\section{Measuring the current and voltage strength of the MFC electrical energy system}

The current strength of the MFC system is measured using a Basic meter (HERMA) and the voltage of the MFC system is measured using the Masda 830B AVOMETER Digital Multitester.

\section{Data analysis}

Data analysis was performed with factorial $4 \times 2$ ANOVA with repeated 3 times.

\section{Results}

\section{Electric energy produced by microbial fuel cell system}

Electrical energy (strong current 1 and voltage V) produced by MFC reactor systems made from mustard and stater vegetable waste that varied and long periods of 5 and 10 days fermentation are presented in Table 1 and Table 2.

\section{Table 1}

Strong electric energy flow of MFC system variation in substrate composition and duration of fermentation

\begin{tabular}{ccccc}
\hline $\begin{array}{c}\text { Factor B } \\
\text { Duration of } \\
\text { Fermentation }\end{array}$ & \multicolumn{4}{c}{ Factor A Substrates and Stater Composition } \\
\cline { 2 - 5 } & $\begin{array}{c}\mathrm{Al} \text { (Garbage mustard } \\
\text { + cow dung) }\end{array}$ & $\begin{array}{c}\mathrm{A} 2 \text { (Garbage }+ \\
\text { EM4) }\end{array}$ & $\begin{array}{c}\text { A3 (Glucose }+ \text { cow } \\
\text { dung) }\end{array}$ & $\begin{array}{c}\text { A4 (Glucose }+ \\
\text { EM4) }\end{array}$ \\
\cline { 2 - 5 } 5 days & $1(\mathrm{~mA})$ & $1(\mathrm{~mA})$ & $1(\mathrm{~mA})$ & $1(\mathrm{~mA})$ \\
& 5.18 & 15.2 & 8.0 & 20.1 \\
Average & 5.12 & 15.2 & 7.9 & 20.1 \\
10 days & 5.12 & 15.2 & 8.0 & 20.1 \\
& 5.14 & 15.2 & 7.93 & 20.1 \\
& 1.51 & 5.3 & 4.1 & 8.24 \\
Average & 1.44 & 5.3 & 3.8 & 8.20 \\
& 1.50 & 5.3 & 4.0 & 8.20 \\
\end{tabular}


Table 2

Electric energy voltage microbial fuel cell system variation in substrate composition and duration of fermentation

\begin{tabular}{ccccc}
\hline $\begin{array}{c}\text { Factor BDuration } \\
\text { of Fermentation }\end{array}$ & \multicolumn{4}{c}{ Factor A Substrates and Stater Composition } \\
\cline { 2 - 5 } & $\mathrm{Al}$ (Garbage mustard & $\mathrm{A} 2($ Garbage + & $\mathrm{A} 3($ Glucose + & A4 (Glucose + \\
& + cow dung) & $\mathrm{EM4})$ & $\mathrm{V}(\mathrm{mV})$ & $\mathrm{VM4})$ \\
\cline { 2 - 5 } & $\mathrm{V}(\mathrm{mV})$ & $\mathrm{V}(\mathrm{mV})$ & 42.3 & 72.1 \\
5 days & 27.01 & 68.8 & 42.4 & 72.2 \\
& 26.88 & 68.7 & 42.3 & 72.1 \\
Average & 27.00 & 68.8 & 42.3 & 72.13 \\
& 26.96 & 68.76 & 10.6 & 35.0 \\
10 days & 5.2 & 23.2 & 10.7 & 34.9 \\
& 5.1 & 23.3 & 10.6 & 34.9 \\
Average & 5.2 & 23.3 & 10.63 & 34.9 \\
\hline
\end{tabular}

The results of factorial ANOVA analysis using the SPSS program for electrical energy data (Flow) from the Microbial Fuel Cell reactor are presented in Table 3. and the voltage (Volt) is presented in Table 4.

\section{Table 3}

ANAVA electric current

Dependent Variable: Ampere_Value

\begin{tabular}{llllll}
\hline Source & $\begin{array}{l}\text { Type III Sum } \\
\text { of Squares }\end{array}$ & Df & Mean Square & F & Sig. \\
\hline Corrected Model & $813.244^{\mathrm{a}}$ & 7 & 116.178 & 31153.800 & .000 \\
lntercept & 1702.019 & 1 & 1702.019 & 456407.286 & .000 \\
composition & 410.233 & 3 & 136.744 & 36668.864 & .000 \\
lama_fermentation & 325.091 & 1 & 325.091 & 87175.295 & .000 \\
composition * & 77.920 & 3 & 25.973 & 6964.905 & .000 \\
lama_fermentation & & & & & \\
$\begin{array}{l}\text { Error } \\
\text { Total }\end{array}$ & .060 & 16 & .004 & & \\
Corrected Total & 2515.323 & 24 & & & \\
\hline
\end{tabular}

Table 4

Electric voltage ANAVA

Dependent Variable: Volt_Value

\begin{tabular}{|c|c|c|c|c|c|}
\hline Source & $\begin{array}{l}\text { Type Ill Sum } \\
\text { of Squares }\end{array}$ & Df & $\begin{array}{l}\text { Mean } \\
\text { Square }\end{array}$ & $\mathrm{F}$ & Sig. \\
\hline Corrected Model & $12770.023^{a}$ & 7 & 1824.289 & 510886.062 & .000 \\
\hline Intercept & 30287.905 & 1 & 30287.905 & 8482026.932 & .000 \\
\hline composition & 5368.911 & 3 & 1789.637 & 501181.876 & .000 \\
\hline lama_fermentation & 6956.075 & 1 & 6956.075 & 1948025.532 & .000 \\
\hline $\begin{array}{l}\text { composition * } \\
\text { lama_fermentation }\end{array}$ & 445.038 & 3 & 148.346 & 41543.758 & .000 \\
\hline Error & .057 & 16 & .004 & & \\
\hline Total & 43057.985 & 24 & & & \\
\hline Corrected Total & 12770.080 & 23 & & & \\
\hline
\end{tabular}


ANAVA test results (Table 3 and Table 4) show that the substrate composition and fermentation time affect the electric current and voltage (voltage) of electrical energy produced by the Microbial Fuel Cell (MFC) reactor with variations in the composition of vegetable mustard and glucose waste substrates, dirt stater cattle and EM4 with a fermentation period of 5 days and 10 days. The highest electric energy flow $(20.1 \mathrm{~mA})$ and the highest voltage $(72.13 \mathrm{mV})$ produced by MFC reactor with glucose substrate composition, EM4 starter with 5 days fermentation time, followed by treatment of mustard trash substrate composition, EM4 starter with 5 days fermentation time. The longer the fermentation process, the current and voltage of the electrical energy produced by the MFC system decreases (Scott et al., 2007). Even so, in terms of economics, the use of vegetable mustard waste substrate material with EM4 starter in the Microbial Fuel Cell (MFC) reactor has the potential to be developed compared to using glucose substrate materials whose prices are relatively more expensive. The Microbial Fuel Cell (MFC) reactor made from substrate of vegetable mustard waste with EM4 starter has the opportunity to be developed as a source of renewable alternative energy, economical and environmentally friendly, both in cities and in rural areas, especially those that lack electricity supply.

\section{Discussion}

Microorganisms can change chemical energy stored inside organic components into electrical energy during incubation in Microbial Fuel Cell (MFC), so that bacteria inside MFC can used to produce power electricity while consuming waste (Romadhoni and Putu, 2014). Womb degradation process organic in order to produce liquid waste, this bio-electricity certainly requires microbes parser. Ibrahim et al. (2017) reported that MFC modeling uses activated sludge in fishery wastewater can be applied to produce bio-electricity. Microbial content in the mud active can be used on the MFC system to produce electrical energy through the process of destroying compounds organic (Silaban and Simamora, 2018). Active mud is an ecosystem which is a complex consisting of bacteria, protozoa, viruses, and organisms other. The activated sludge is usually consists of a combination of decomposing bacteria e.g. Aerobacter sp., Nitrobacter sp., Nitrosomonas sp., And bacterial strains other decomposers who are able to degrade organic content for example accelerates fermentation process of dissolved organic waste in water and reduce the content organics in wastewater. Utilization activated sludge is also expected to be able to used on MFC systems, so besides degrade organic content in fisheries liquid waste, use of mud the active can also produce bio-electricity. Electrical data generated using types of graphite plate electrodes and rods graphite is $0.5-0.6$ volts, then as an effort utilization, fisheries industry wastewater this can be used as a deep substrate MFC system for electricity production.

Utilization of industrial wastewater fisheries in the MFC system are expected can be an alternative waste treatment which has been used and can overcome the main problems caused by wastewater, that is odor that is not delicious which causes discomfort to the surrounding community. Results of research this is also expected to be wrong one step ahead to get new and renewable energy sources, so use of MFC systems with water susbstrat waste can reduce energy consumption fossils (Du et al. 2007; Nasution and Silaban, 2017). Waste water treatment using Anaerobic biofilter is a technology inexpensive processing, easy operation and saving energy. Technology concept processing with anaerobic biofilter is a term from the developed reactor with the principle of microbes growing and developing stick to a filter media (media attached) and form a biofilm (attached growth). Biofilter can be used for water waste with a large COD load and can remove suspended solids (SS) well (Wijeyekoon et al. 2004). 


\section{Conclusion}

Substrate composition, temperature and duration of substrate fermentation and interaction of substrate composition with fermentation duration in the Microbial Fuel Cell (MFC) reactor system affect the electrical energy produced by the system. The highest electrical current (20.1 $\mathrm{mA})$ and voltage $(72.13 \mathrm{mV})$ is produced by the MFC reactor with the composition of the glucose substrate, EM4 starter with a 5 day fermentation period, followed by the composition of the mustard vegetable waste substrate, EM4 starter with fermentation time of 5 days $(15.2 \mathrm{~mA}$ and $68.76 \mathrm{mV}$ ). The Microbial Fuel Cell (MFC) reactor made from vegetable mustard waste substrate with EM4 starter has the opportunity to be developed as a source of renewable alternative energy because it is relatively cheaper compared to using glucose substrates.

\section{Acknowledgments}

Thank you to the Ministry of Research, Technology and Higher Education Simbelmawa for the 2018 PKM grant that has been given for the implementation of the PKM-PE that has been implemented.

\section{References}

Cheng, S., Liu, H., \& Logan, B. E. (2006a). Increased performance of single chambered MFCs using an improved cathode structure. Electro. Chem. Biocommunity, 8(3), 888-891, doi: 10.1016/j.elecom.2006.01.010

Cheng, S., Liu, H., \& Logan, B. E. (2006b). Increased power generation in a continuous flow mfc with advective flow through the porous anode and reduced electrode spacing. Environmental Science \& Technology, 40(7), 2426-2432, doi: 10.1021/es051652w

Du Z., Li H., Gu T. 2007. A state art review on microbial fuel cells: a promising technology for wastewater treatment and bioenergy. Biotechnology Advances, 25(5), 464-482, doi: 10.1016/j.biotechadv.2007.05.004

Ibrahim, B., Suptijah, P., \& Adjani, Z. N. (2017). Kinerja microbial fuel cell penghasil biolistrik dengan perbedaan jenis elektroda pada limbah cair industri perikanan. Jurnal Pengolahan Hasil Perikanan Indonesia, 20(2), 296-304.

Liu, H., \& Logan, B. E. (2004). Electricity generation using an air-cathode single chamber microbial fuel cell in the presence and absence of a proton exchange membrane. Environmental science $\mathcal{\&}$ technology, 38(14), 4040-4046, doi: 10.1021/es0499344

Nasution, H. I., \& Silaban, S. (2017). analisis logam berat pb dan cd dalam air sumur di sekitar lokasi pembuangan sampah akhir. Jurnal ITEKIMA, 1(1), 17-24.

Pandey, B. K., Mishra, V., \& Agrawal, S. (2011). Production of bio-electricity during wastewater treatment using a single chamber microbial fuel cell. International Journal of Engineering, Science and Technology, 3(4), 42-47, doi: 10.4314/ijest.v3i4.68540

Purwono, P., Hermawan, H., \& Hadiyanto, H. (2015). Penggunaan teknologi reaktor microbial fuel cells (Mfcs) dalam pengolahan limbah cair industri tahu untuk menghasilkan energi listrik. Jurnal Presipitasi: Media Komunikasi dan Pengembangan Teknik Lingkungan, 12(2), 57-65.

Romadhoni, H. A., \& Putu, W. (2014). Pembuatan biogas dari sampah pasar. Envirotek: Jurnal Ilmiah Teknik Lingkungan, 6(1), 59-64.

Sari, D. A., Ratnasari, E., \& Fitrihidajati, H. (2015). Pemanfaatan limbah ternak kambing etawa sebagai bahan pupuk organik cair untuk budi daya baby corn. LenteraBio, 4(2), 143-149.

Scott, K., \& Murano, C. (2007). Microbial fuel cells utilising carbohydrates. Journal of Chemical Technology \& Biotechnology: International Research in Process, Environmental \& Clean Technology, 82(1), 92-100, doi: 10.1002/jctb.1641

Silaban, S., \& Simamora, P. (2018). Isolasi dan karakterisasi bakteri penghasil amilase dari sampel air tawar Danau Toba. EduChemia (Jurnal Kimia dan Pendidikan), 3(2), 222-231.

Wijeyekoon, S., Mino, T., Satoh, H., \& Matsuo, T. (2004). Effects of substrate loading rate on biofilm structure. Water Research, 38(10), 2479-2488, doi: 10.1016/j.watres.2004.03.005 